\title{
Cikkismertetés: Egy dán egészségtámogató iskolai intervenciós program megvalósulásának értékelése
}

\author{
Article review: Process evaluation of implementation fidelity in a Danish \\ health-promoting school intervention
}

Ismertető: $\quad$ Varga-Nagy Veronika $\square$

Országos Gyógyszerészeti és Élelmezés-egészségügyi Intézet

Ismertetett cikk: Ane HØstgaard Bonde, Nanna Wurr Stjernqvist, Marianne S. Sabinsky, Helle Terkildsen Maindal: 2018 december 27., BMC Public Health online, https://doi.org/10.1186/s12889$\underline{018-6289-5}$

Beküldve: $\quad$ 2019. 02. 01.

doi: $\quad$ 10.24365/ef.v60i1.416

Kulcsszavak: egészségfejlesztés; iskola; komplex intervenció

Keywords: health promotion; school; complex intervention

A tanulmány a „We Act” elnevezésű, átfogó, a gyerekeket, a tanárokat és a szülőket egyaránt bevonó dán iskolai egészségtámogató intervenció hatékonyságát vizsgálta. A program célja, hogy javítsa a tanulók étkezési szokásait, fizikai aktivitását, jóllétét, illetve szociális készségét. Ennek eléréséhez az ,Investigation, Vision, Action \& Change" (IVAC) oktatási módszert alkalmazták, melynek keretében a gyermekeket az egészséges iskolai és otthoni környezet kialakításában való aktív közremúködésre sarkallták.

\section{A program fő elemei:}

1. „Investigation” (vizsgálat) - az első fázis a gyerekek táplálkozásának és fizikai aktivitásának felmérése táplálkozási napló és lépésszámláló segítségével.

2. „Vision” (elképzelés) - a második szakaszban a tanulók kidolgozzák a saját iskolai egészségtámogató akcióterveiket, és azt bemutatják az egész iskola előtt.

3. „Action \& Change” (akció és változás) - zárásként a gyerekek megvalósítják az említett terveket az intézmény, a tanárok és a szülők támogatásával.
Az iskolai oktatásba fonódó elemek mellett a program része a szülők hiteles tájékoztatása az egészséges életmóddal kapcsolatban szórólapok és közösségi felületek segítségével, valamint szakmai múhelyek szervezése és egy intézményi egészségbizottság felállítása.

A kutatók az értékelés során az Orvosi Kutatóbizottság (The Medical Research Council) új irányelvét vették alapul. Ennek mentén kérdőíveket töltettek ki a résztvevő gyerekekkel és azok szüleivel, valamint interjúkat készítettek és helyszíni megfigyelést is végeztek, így biztosítva a hatékonyságot befolyásoló tényezők komplex vizsgálatát.

A program részei közül az "akció és változás” fázis bizonyult a legkevésbé, a „vizsgálat és elképzelés” pedig a leginkább múködőképesnek. A tanárok véleménye szerint a lépésszámlálás és a táplálkozási naplók kitöltése volt a leginkább beilleszthető a tanórákba. Nagyon motiválta a diákokat, hogy bemutathatták az egészségtámogató akciótervötleteiket, ugyanakkor a lelkesedésüktől és a kezdeti sikerektől függetlenül ezeket az ötleteket sajnos nem sikerült hosszú távon fenntartani egyik iskolában sem. 
A hatékony múködést befolyásoló környezeti tényezők közül a szülők bizonyultak a legnagyobb kihívásnak, akik jellemzően sem a program megvalósításában, sem az eredmények mérésében nem vettek részt aktívan.

Problémát jelentett továbbá, hogy az iskola vezetésének támogatása nem volt teljes körü. $\mathrm{A}$ bevont tanárok csupán kevesebb, mint fele értékelte pozitívan a programot. Legtöbben úgy ítélték meg, hogy az nem igazán illeszthető bele az iskolai tantervbe.

A vizsgálat során a kutatók összességében azt tapasztalták, hogy bár a program széleskörű, több környezeti tényezőt is figyelembe vesz, hatása mégsem volt kifejezetten mérhető. Feltételezésük szerint a hatékonyságot növelhetné a munkában résztvevő oktatók alaposabb, hosszabb ideig tartó felkészítése.

\section{TANULSÁGOK A HAZAI SZAKEMBEREK SZÁMÁRA}

Habár a „We Act” egy evidenciákon alapuló, a gyerekeket, a tanárokat és a szülőket egyaránt bevonni kívánó egészségtámogató program, hosszú távon a módszer mégsem tudott jelentős változásokat eredményezni. A kutatók ennek okát többek között az iskolák és a tanárok rövid felkészítési idejében vélik felfedezni. A tanulmány rávilágít arra is, hogy ahogy az más hasonló iskolai egészségtámogató intervencióknál is megfigyelhető, a program múködésében a legnagyobb kihívást a szülők bevonása jelenti, illetve kulcsfontosságú, hogy az adott intézmény vezetősége mennyire támogató. 